\title{
Reduction of curd-forming period in Shrikhand manufacturing process
}

\author{
by \\ R.S. PATEL* and B.K. CHAKRABORTY**
}

\author{
Ré s u m é \\ RÉDUCTION DU TEMPS DE COAGULATION \\ LORS DE LA FABRICATION DE « SHRIKHAND »
}

\begin{abstract}
Plusieurs mélanges de streptocoques et de lactobacilles lactiques étaient testés pour leur aptitude à former un gel à partir de lait convenant à la transformation en "Shrikhand ". Le meilleur résultat était obtenu avec un levain à yoghourt qui permettait l'obtention d'un produit satisfaisant en $4 \mathrm{~h}$ au lieu des 8-10 $\mathrm{h}$ requis par le levain traditionnel. A partir de ces résultats, un procédé de fabrication du "Shrikhand " est proposé : le lait écrémé de buflesse $\left(10 \%\right.$ de matière sèche) est traité thermiquement à $85^{\circ} \mathrm{Cel}$ sius pendant 30 min, refroidi à $42^{\circ}$ Celsius et inoculé avec 1 à $2 \%$ de levain à yoghourt. Le caillé égoutté ou "Chakka » obtenu à partir du coagulum formé en $4 \mathrm{~h}$ était additionné des quantités requises de crème concentrée et de sucre pour obtenir un "Shrikhand "satisfaisant sur le plan de la composition $(60 \%$ de matière sèche, $6,0 \%$ de matière grasse et $41 \%$ de sucre) et des qualités organoleptiques.
\end{abstract}

\section{S u m ma ry}

Various cultures of lactic acid bacteria consisting of streptococci and lactobacilli were examined with respect to time required for curd formation and properties of the product. Yoghurt culture (YH) was the most desirable as it produced satisfactory curd within $4 \mathrm{~h}$ thus reducing the curd setting time from $8-10 \mathrm{~h}$ to $4 \mathrm{~h}$.

National Dairy Research Institute, Karnal, India.

Present Address :

* Federal Dairy Research Institute, Kiel, Federal Republic of Germany.

** National Dairy Development Board, Anand, Gujarat, India. 
A standard method was established for manufacture of Shrikhand. The method involved using buffalo skimmilk (10\% total solids) subjected to heat treatment of $85^{\circ} \mathrm{C}$ for $30 \mathrm{~min}$ followed by 1.5 to $2.0 \%$ inoculation of an active $\mathrm{YH}$ culture at $42^{\circ} \mathrm{C}$ for obtaining a curd ( 0.9 lactic acid) at the end of $4 \mathrm{~h}$. Tfe «chakka» obtained from this curd when blended with required quantities of cream and sugar yielded a satisfactory Shrikhand.

Key words :

Shrikhand - Fermented milk - Heat treatment - Acidification - Organoleptic qualities.

\section{INTRODUCTION}

Shrikhand belongs to the group of fermented and coagulated milk product. This indian indigenous dairy product is prepared by lactic coagulation of milk, and expulsion of whey from the curd followed by blending of sugar and flavours. In Shrikhand making technology, preparation of dahi or curd by conventional starter cultures takes about 10-12 hours (h), a time period too long to promote the development of a continuous Shrikhand making process. In the patented process of Aneja et al. (1977), the curd setting step of $8-10 \mathrm{~h}$ at $37^{\circ} \mathrm{C}$ appears to be the longest unit process among all other steps considered. Therefore, need arises to explore the possibility of cutting down further the curd setting time by appropriate selection of starter culture.

In the present investigation several lactic starter cultures were studied for the preparation of Shrikhand. The influence of heat treatment of the milk, time and temperature of incubation, final acidity of curd, and addition of diacetyl on the flavour of Shrikhand is discussed in this paper.

\section{EXPERIMENTAL}

Raw buffalo milk was taken from the herd maintained at the National Dairy Research Institute, Karnal (India). The milk was preheated to $40-45^{\circ} \mathrm{C}$ in a plate heat exchanger (Alfa-Laval), and separated in a Titan separator (Denmark).

Mixed, multistrains starter cultures of LF-40, NDRI $1, \mathrm{NDRI}_{2}$, "A ", and " B » (different strains of Streptococcus lactis and Streptococcus diacetylatis), $\mathrm{S}+\mathrm{L}$ (nonspecified mixture of lactic streptococci and lactobacilli), $\mathrm{DRC}_{1}$ (Streptococcus diacetylactis) $\mathrm{YH}$ (Streptococcus thermophilus + Lactobacillus bulgaricus), and Acidophilus (Lactobacillus acidophilus), were obtained from Dairy Bacteriology Division of the National Dairy Research Institute, Karnal, India. 


\section{Preparation of Shrikhand}

Buffalo skimmilk was heated to $85^{\circ} \mathrm{C}$ for $30 \mathrm{~min}$, and then cooled to $42 \pm 2^{\circ} \mathrm{C}$ and $\mathrm{YH}$ culture (Streptococcus thermophilus + Lactobacillus bulgaricus) was added at the rate of 1.5 to $2.0 \%$ (percent) and incubated for $4 \mathrm{~h}$ at the same temperature so as to get a $\mathrm{pH}$ of 4.6 to 4.4 with the corresponding acidity of 0.85 to $0.90 \%$ lactic acid in curd. In another set of experiment, $1.0 \%$ LF-40 culture was added and the samples were incubated at $30 \pm 1^{\circ} \mathrm{C}$ for 11 to $12 \mathrm{~h}$ to get a $\mathrm{pH}$ of 4.6 to 4.5 with the corresponding acidity of 0.85 to $0.90 \%$ lactic acid. And the resulting curd was subsequently used for the preparation of control Shrikhand samples.

The curd thus obtained was centrifuged for $40 \mathrm{~min}$ in a laboratory basket centrifuge $(1000-1200 \mathrm{rpm})$ to separate out whey. The resultant product called «Chakka » had 22 to $23 \%$ total solids (TS), 13 to $14 \%$ total proteins, and 3.0 to $3.2 \%$ reducing sugar. The lactic acidity and $\mathrm{pH}$ of the chakka varied from 2.0 to $2.1 \%$ and 4.5 to 4.4 respectively (fig. 1). Calculated quantities of sugar and cream, as recommended by Patel and Chakraborty (1982) were mixed with chakka in a planetary mixer (Metrex, New-Delhi) at 30 to $35 \mathrm{rpm}$ for half an hour to get $41 \%$ sucrose and $6 \%$ fat in the finished product.

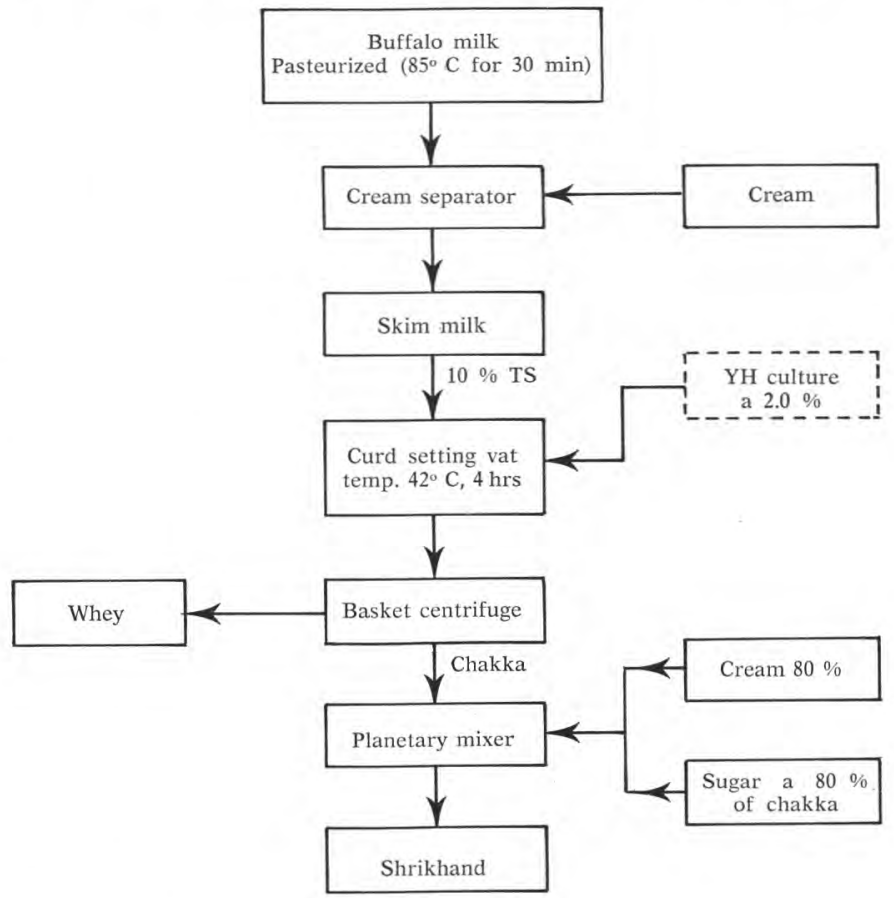

fig. 1

Flow diagram of Shrikhand manufacture

Diagramme de fabrication $d u$ "Shrikhand " 
TABLE 1

Curd forming characteristics of selected lactic cultures

\begin{tabular}{|c|c|c|c|c|c|c|c|c|c|}
\hline \multirow{2}{*}{$\begin{array}{l}\text { Curd* forming } \\
\text { characteristics }\end{array}$} & \multicolumn{9}{|c|}{ Lactic cultures** } \\
\hline & 1 & 2 & 3 & 4 & 5 & 6 & 7 & 8 & 9 \\
\hline Incubation temp $\left({ }^{\circ} \mathrm{C}\right)$ & 30 & 37 & 37 & 30 & 42 & 37 & 37 & 37 & 37 \\
\hline Time required to reach $\mathrm{pH} 4.6(\mathrm{~h})$ & 11 & 9 & 10 & 11 & 4 & 9 & 9 & 9 & 6 \\
\hline Flavour*** & +++ & ++ & ++ & +++ & + & + & + & ++ & + \\
\hline TVFA $(0.01 \mathrm{~N} \mathrm{NaOH} / 50 \mathrm{~g}$ of curd) & 10.10 & 6.00 & 5.70 & 10.80 & 2.40 & 4.20 & 5.90 & 7.00 & 4.50 \\
\hline Curd tension (g) & $\begin{array}{l}86.90 \\
86.90\end{array}$ & 73.60 & 78.30 & 66.30 & 98.70 & 69.80 & 71.80 & 81.30 & 83.40 \\
\hline
\end{tabular}

* Buffalo skimmilk of $10 \%$ TS and heated to $85^{\circ} \mathrm{C}$ for $10 \mathrm{~min}$ were inoculated with $1 \%$ cultures.

** 1, LF-40, $2 \mathrm{NDRI}_{1}, 3 \mathrm{NDRI}_{2}, 4 \mathrm{DRC}_{1}, 5 \mathrm{YH}, 6$ Acidophilus, 7 «B», 8 «A», $9 \mathrm{~S}+\mathrm{L}$.

$* * *+++$ culture flavour pronounced, ++ moderate, + slight. 


\section{Curd tension}

The tension of the curd was measured by the method of Chandrashekhar et al. (1957) with the following modification. A $50 \mathrm{ml}$ portion of milk was taken in a $100 \mathrm{ml}$ beaker $(7 \times 4.5 \mathrm{~cm})$ and a « $H$ » shape blade was put in it. The milk was then inoculated with the starter culture and incubated for a specified period of time (Table 1). At the end of the incubation period, the weight required to pull the knife through the curd mass was recorded and expressed in gram.

\section{Total volatile fatty acids (TVFA)}

The volatile fatty acids were determined by the method of Hempenions and Liska (1968) with slight modification. Fifty grammes of the sample were weighed and transferred to a $800 \mathrm{ml} \mathrm{Kjeldahl} \mathrm{flask}$ and $3.0 \mathrm{ml}$ of $1 \mathrm{~N} \mathrm{H}_{2} \mathrm{SO}_{4}$ was added. The contents were then steam distilled and about $100 \mathrm{ml}$ of the distillate was collected and titrated using $0.01 \mathrm{~N} \mathrm{NaOH}$ and the total volatile fatty acids contents was expressed as $\mathrm{ml}$ of $0.01 \mathrm{~N} \mathrm{NaOH}$ per $50 \mathrm{~g}$ of the sample.

\section{Sensory evaluation}

The samples of Shrikhand were subjected to sensory evaluation by a panel of six judges, using 9 points hedonic scale. (Liked-extremely 9 points, liked very much 8 points, liked moderately 7 points, liked slightly 6 points, neither liked nor disliked 5 points, disliked slightly 4 points, disliked moderately 3 points, disliked very much 2 points and disliked extremely 1 point).

\section{RESULTS AND DISCUSSION}

\section{Choice of starter culture}

It can be seen from Table-1 that as expected, the time required to reach a pH level of 4.6 is related to the incubation temperature. The longest time of $11 \mathrm{~h}$ was taken by $\mathrm{LF}-40$ and $\mathrm{DRC}_{1}$ at $30^{\circ} \mathrm{C}$, while shortest time of $4 \mathrm{~h}$ was required by $\mathrm{YH}$ culture working at $42^{\circ} \mathrm{C}$. However, the culture varies markedly among them, even when the same incubation temperature were used.

At $37^{\circ} \mathrm{C}$ temperature, the $\mathrm{pH}$ reached by $\mathrm{S}+\mathrm{L}$ culture in $6 \mathrm{~h}$ was attained by the other cultures in 9 to $10 \mathrm{~h}$. The flavour quality of the lactic culture, $\mathrm{LF}-40$ and $\mathrm{DRC}_{1}$ the slowest acid producers, was judged to be best in term of the development of a desirable mild aroma. In this regard $\mathrm{YH}$, acidophilus, " $\mathrm{B}$ » and $\mathrm{S}+\mathrm{L}$ exhibited only slight aromatic flavour. The level of TVFA exhibited a general relationship with the flavour traits, being highest for $L F-40$ and $D_{R} C_{1}$, 
and lowest for the YH. Although fast acid producing culture are known to be associated with the development of bitter taste, no such defect was detected in curd prepared from YH culture. Curd tension properties of this culture did not show any relationship with the other parameters such as the rate of acid development, flavour or TVFA. YH exhibited the highest curd tension value of $98.70 \mathrm{~g}$, while $\mathrm{DRC}_{1}$ had a lowest value of $66.30 \mathrm{~g}$. In general YH culture could be considered most desirable for Shrikhand manufacture.

\section{Heat treatment of milk}

A YH culture is basically a yoghurt culture containing a mixture of $S$. thermophilus and L. bulgaricus. Heat treatment of milk prior to inoculation of a starter culture, plays a significant role in acid development. It can be seen from Fig. 2a, as the intensity of heat treatment of milk increased, the rate of acid development as well as the final acidity also increased. The effect of heat-treatment on reducing the $\mathrm{pH}$ of various curd system were similar to the effect on acidity development (Fig. 2 b). Also it was observed that as the incubation time increased, the differences with level of $\mathrm{pH}$ became more pronounced among the various samples. The favourable influences of high heat treatment on acid development, might be because of possible

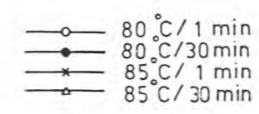

(a)

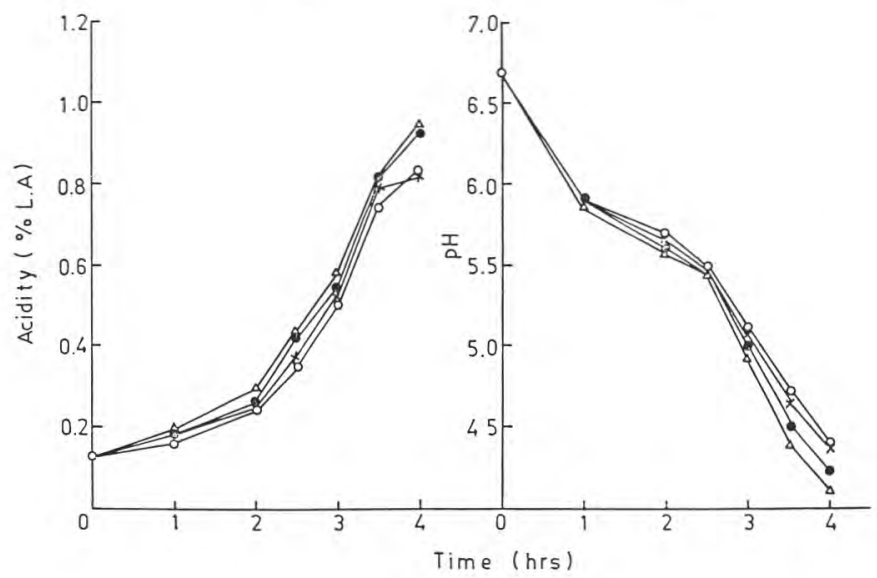

fig. 2

Effect of heat treatment of milk on the rate of acid development and changes in $\mathrm{pH}$ using $\mathrm{YH}$ culture. 
destruction of heat labile inhibitory compounds and also the heat induced formation of growth stimulants such as peptides, aminoacids, and formic acid which have been reported to enhance acid production by (Miller et al., 1964). Thus the highest heat treatment, viz. $85^{\circ} \mathrm{C}$ for 30 min giving a pH 4.0-4.2 and acidity $0.90-0.95 \%$ lactic acid was selected for Shrikhand manufacture.

\section{Effect of incubation temperature and amount of starter culture on curd firmness}

Firmness of the curd used for chakka making is an important property mainly from the point of view of solids losses in whey. The effect of adding $\mathrm{YH}$ culture to buffalo skimmilk at $37^{\circ} \mathrm{C}$ and $42^{\circ} \mathrm{C}$ for $4 \mathrm{~h}$ can be seen from Table-2. The curd tension was somewhat higher with the higher incubation temperature. For all the three rates of inoculation, with the increasing inoculation rate, the curd tension also increased. However, $1.5 \%$ level of inoculation gave a substantially firmer curd as compared to that obtained at $1.0 \%$. There was only a slight difference between 1.5 and $2.0 \%$ levels. Accordingly, the inoculum levels of 1.5 to $2.0 \%$ were selected for Shrikhand manufacture.

TABLE 2

Effect of incubation temperature and amount of inoculum on curd firmness

\begin{tabular}{c|c|c}
\hline \multirow{2}{*}{$\begin{array}{c}\text { Inoculum } \\
\%\end{array}$} & \multicolumn{2}{|c}{ Curd tension $(\mathrm{g})$ at } \\
\cline { 2 - 3 } & $37^{\circ} \mathrm{C}$ & $42^{\circ} \mathrm{C}$ \\
\hline 1 & 83.56 & 92.80 \\
1.5 & 90.82 & 98.30 \\
2 & 91.70 & 99.35 \\
\hline
\end{tabular}

\section{Effect of curd acidity on Shrikhand flavour}

The flavour quality of Shrikhand is greatly influenced by the level of the developed acidity at which curd is converted to chakka, and chakka in turn to Shrikhand. Three levels of acidity were, therefore, developed in the curds viz. $0.81,0.90$ and $0.98 \%$ lactic acid for their conversion to chakka. The chakka samples were then blended with 
sugar and cream to a final compositional level of approximatively $40 \%$ sugar and $6 \%$ fat in Shrikhand. The data on the organoleptic evaluation of these Shrikhand samples are presented in Table 3. The titratable acidity of chakka exhibited a corresponding increase as the curd acidity increased.

On the basis of flavour score, a curd acidity of $0.81 \%$ lactic acid was considered too low as the Shrikhand was criticized as mildly acid and too sweet. A titratable acidity of curd in the range of 0.90 to $0.98 \%$ lactic acid appeared to result in most desirable Shrikhand flavour, as was also reported by Aneja et al. (1977).

TABLE 3

Effect of curd acidity on the sensory quality of Shrikhand

\begin{tabular}{|c|c|c|c|c|}
\hline \multicolumn{3}{|c|}{$\%$ Lactic acid } & \multirow{2}{*}{$\begin{array}{l}\text { Flavour* } \\
\text { score }\end{array}$} & \multirow[b]{2}{*}{ Criticism } \\
\hline $\begin{array}{c}\text { Acidity } \\
\text { of } \\
\text { curd }\end{array}$ & $\begin{array}{c}\text { Acidity } \\
\text { of } \\
\text { chakka }\end{array}$ & $\begin{array}{l}\text { Acidity } \\
\text { of } \\
\text { Shrikhand }\end{array}$ & & \\
\hline 0.81 & 1.94 & 0.99 & 6.93 & $\begin{array}{l}\text { too sweet, lacking } \\
\text { mild acidic flavour }\end{array}$ \\
\hline 0.90 & 2.11 & 1.08 & 7.34 & $\begin{array}{l}\text { mild acidic flavour, } \\
\text { optimum sugar level }\end{array}$ \\
\hline 0.98 & 2.70 & 1.39 & 7.36 & Slight acidic flavour \\
\hline
\end{tabular}

* On a 9-points hedonic scale, ranging from 9 (like extremly) to 1 (dislike extremely).

\section{Effect of diacetyl addition on the flavour of Shrikhand obtained with the use of $\mathrm{YH}$ culture}

Earlier it was noticed that the curd obtained with the $\mathrm{YH}$ culture had a less desirable aromatic property than that obtained with cultures known to produce diacetyl (Table 1). In order to improve the flavour of the curd from YH culture, addition of diacetyl at 10, 15, 20 and $25 \mathrm{ppm}$ levels in Shrikhand was investigated. The experimental product was compared with the reference product obtained by using LF-40, a diacetyl producing culture. From Table 4, it can be seen that diacetyl added at the rate of $10 \mathrm{ppm}$ improved the flavour score from 6.66 to 7.26 (on nine points hedonic scale), which was fairly comparable in with the reference sample score of 7.42 , further increase in the diacetyl level decreased the flavour score, the product flavour tended to be harsh and unnatural. 
TABLE 4

Effect of diacetyl addition on the flavour of Shrikhand obtained with $\mathrm{YH}$ culture

\begin{tabular}{|c|c|c|c|c|c|c|c|}
\hline \multirow{2}{*}{$\begin{array}{c}\text { Reference } \\
\text { sample* }\end{array}$} & \multicolumn{5}{|c|}{$\begin{array}{c}\text { Diacetyl level in experimental sample } \\
(\mathrm{ppm})\end{array}$} & \multirow{2}{*}{$\begin{array}{l}\text { Experimental } \\
\text { sample with } \\
\text { cardamom } \\
\text { (a) } 1 \mathrm{~g} / 1 \mathrm{~kg} \\
\text { of Shrikhand }\end{array}$} & \multirow{2}{*}{$\begin{array}{l}\text { Reference } \\
\text { sample + } \\
\text { cardamom } \\
\text { (a) } 1 \text { g/1kg } \\
\text { of Shrikhand }\end{array}$} \\
\hline & 0 & 10 & 15 & 20 & 25 & & \\
\hline 7.42 & 6.66 & 7,26 & 7.15 & 7.11 & 6.95 & 7.38 & 7.54 \\
\hline $\begin{array}{l}\text { pleasant } \\
\text { aromatic } \\
\text { flavour }\end{array}$ & flat & $\begin{array}{l}\text { pleasant } \\
\text { flavour }\end{array}$ & $\begin{array}{l}\text { slightly } \\
\text { harsh } \\
\text { flavour }\end{array}$ & $\begin{array}{c}\text { definitively } \\
\text { harsh } \\
\text { flavour }\end{array}$ & $\begin{array}{l}\text { unnatural } \\
\text { flavour }\end{array}$ & $\begin{array}{l}\text { pleasant } \\
\text { flavour }\end{array}$ & $\begin{array}{l}\text { pleasant } \\
\text { flavour }\end{array}$ \\
\hline
\end{tabular}

* Reference sample was prepared with LF-40 culture $\left(1 \%\right.$ inoculum at $\left.30^{\circ} \mathrm{C}\right)$.

** Experimental sample was prepared with $\mathrm{YH}$ culture $\left(2 \%\right.$ inoculum at $\left.42^{\circ} \mathrm{C}\right)$. 
It is not worthy, however, that the favourable influence of the diacetyl adding (10 ppm), Shrikhand flavour was no longer perceptible when cardamom was used for flavouring the product (as usually is practice in traditional Shrikhand making), apparently because of the masking effect of cardamom. Therefore, flavour enrichment of the YH culture product with diacetyl was thought unnecessary. However, a comparison of cardamom containing samples, prepared from LF-40 and YH cultures, without added diacetyl revealed little difference in the preference score, indicating an effective masking action of cardamom flavour which predominates the system. Therefore flavour enrichment with diacetyl was thought unnecessary.

\section{CONCLUSION}

From the present investigation it could be concluded that the yoghurt culture (YH) was the most desirable as it produced satisfactory curd within $4 \mathrm{~h}$, thus reducing the curd setting time from $8-10 \mathrm{~h}$ to $4 \mathrm{~h}$. The heat treatment of milk prior to inoculation at $85^{\circ} \mathrm{C}$ for $30 \mathrm{~min}$, had a favourable influence on acid development. The inoculum level of 1.5 to $2.0 \%$ and incubation temperature of $42^{\circ} \mathrm{C}$ gave a firmer curd as compared to inoculum level of $1.0 \%$, and incubation temperature of $37^{\circ} \mathrm{C}$. A titratable acidity of 0.90 to $0.98 \%$ lactic acid in the curd, gave most desirable Shrikhand. Flavour enrichment with diacetyl did not have any favourable influence on the flavour score of the finished product.

\section{References}

Aneja (R.P.), Vyas (M.N.), Karan (Nanda), Thareja (V.K.) (1977). - Development of an Industrial process for the manufacture of Shrikhand. Journal of food science and Technology, 14, 159-163.

Chandrashekhara (M.R.), Swaminathan (M.), Bhatia (D.S.), Subramanayam (V.) (1957). - Infant food from buffalo milk. Effect of different treatment on curd tension. Food Science, 6, 226-228.

HeMPENIOUS (W.L.), DisKa (B.J.) (1968). - Method for determining volatile acids in cultured dairy products. Journal of Dairy Science, 51, 221-222.

MiLler (I.), MARTin (H.), KANDLER (O.) (1964). - The spectrum of aminoacids in yoghurt. Milch wissenschaft, 19, 18-25.

Patel (R.S.), Chakraborty (B.K.) (1982). - Process alterations in Shrikhand Technology. Ph.D. Thesis, submitted to Kurukshetra University. 